\title{
Zasoby lokalne jako potencjały rozwoju lokalnego w dokumentach strategicznych na przykładzie wybranych gmin wiejskich województwa śląskiego
}

\section{Local resources as potential for local development in the strategic documents based on selected Silesian Province's rural communes}

\author{
Małgorzata SURMACZ \\ Uniwersytet Jagielloński \\ Zakład Geografii Ludności, Osadnictwa i Rolnictwa \\ ul. Gronostajowa 7, 30-387 Kraków \\ malgorzata.surmacz@gmail.com
}

\begin{abstract}
Zarys treści: Głównym celem niniejszego opracowania jest ocena jakości zasobów lokalnych identyfikowanych przez gminy w dokumentach strategicznych w kontekście możliwego znaczenia tych zasobów jako potencjałów rozwojowych. Do realizacji celu sformułowano pytania badawcze dotyczące charakteru identyfikowanych w gminach zasobów lokalnych, możliwości identyfikacji zasobów priorytetowych oraz możliwości ich uznania za potencjał rozwojowy. W artykule zaprezentowano również relację między zastosowanymi pojęciami: zasób lokalny, zasób priorytetowy oraz potencjał rozwoju. Badaniem objęto strategie rozwoju pięciu gmin wiejskich województwa śląskiego, koncentrując się na części diagnostycznej (w tym szczególnie na „mocnych stronach” - efekcie analiz SWOT) oraz fragmentach dokumentów poświęconych celom strategicznym.
\end{abstract}

Słowa kluczowe: zasoby lokalne, potencjały rozwoju, strategie rozwoju lokalnego, zasoby, rozwój gminy, województwo śląskie, gminy wiejskie.

\section{Wprowadzenie}

Gmina jako podstawowa jednostka samorządu terytorialnego jest ustawowo odpowiedzialna za rozwój społeczno-gospodarczy oraz zagospodarowanie przestrzenne swojego obszaru, przy czym obecnie - zgodnie z koncepcją rozwoju lokalnego czy ruchu odnowy wsi - wskazuje się, że rozwój ten powinien być oparty na lokalnych zasobach, także lokalnych czynnikach rozwoju (por. Brol 1998; Parysek 2001; Sekuła 2004)1. Takie podejście jest szczególnie istotne wśród gmin wiejskich, ponieważ niewiele z nich osiągnęło sukces dzięki innym czynnikom, w tym np. inwestorom zewnętrznym (Kłodziński 2009).

\footnotetext{
1 Także - jak wskazuje koncepcja rozwoju neoendogennego - z uwzględnieniem zewnętrznych szans rozwojowych (Ray 2001).
} 
Podkreślić jednak należy, że wykorzystanie zasobów lokalnych w praktyce wymaga ich szczegółowej identyfikacji, selekcji, rzetelnej waloryzacji, a nawet pewnej wiary samorządów w to, że lokalne zasoby, którymi dysponują, mogą stanowić o możliwości przyszłego rozwoju (Parysek 2015). „Miejscem” identyfikacji lokalnych zasobów oraz wyboru tych, które planuje się wykorzystać dla zdynamizowania procesu rozwojowego jest dokument strategiczny (najczęściej strategia rozwoju gminy, dalej: SRG), który stanowi artykulację refleksji o rozwoju gminy, i który powinien służyć planowaniu oraz koordynacji wdrażania procesów rozwojowych w oparciu o: rzetelnie zdiagnozowane zasoby, ocenę uwarunkowań zewnętrznych wraz z uwzględnieniem pożądanych kierunków rozwoju w sferze społecznej, gospodarczej i przestrzennej (Wiatrak 2011). Warto podkreślić, że dokument ten jest jednym z kluczowych, choć nieobligatoryjnych, narzędzi zarządzania strategicznego; jest przyjmowany uchwałą rady gminy, a w praktyce stanowi akt kierownictwa wewnętrznego (Parysek 2015), który poprzez świadomy wybór priorytetów pozwala - przynajmniej teoretycznie ${ }^{2}$ - na racjonalizację gospodarowania środkami publicznymi (Kłodziński 2009, Rzeszutko-Piotrowska 2013).

W związku ze znaczeniem SRG jako miejsca identyfikacji, selekcji oraz zaplanowania działań (z uwzględnieniem środków finansowych) związanych z wykorzystaniem określonych zasobów lokalnych, głównym celem niniejszego opracowania jest ocena jakości zasobów lokalnych identyfikowanych przez gminy w dokumentach strategicznych w kontekście ich (zasobów lokalnych) możliwego znaczenia jako potencjałów rozwojowych, przeprowadzona na przykładzie SRG wybranych gmin wiejskich województwa śląskiego. Warto podkreślić, że osiągnięcie powyższego celu może mieć istotne znaczenie praktyczne, ponieważ niewłaściwy wybór przez gminę najważniejszych zasobów może wiązać się z niekorzystnymi konsekwencjami, w tym przede wszystkim z rozpraszaniem środków publicznych i nieefektywnością działania.

W pracy sformułowano następujące pytania badawcze:

1) Jakie zasoby lokalne są identyfikowane w poszczególnych SRG?

2) Czy na podstawie SRG można określić zasoby uznawane przez gminy za priorytetowe?

3) Czy zasoby uznane za priorytetowe stanowią potencjały rozwojowe?

Poniżej przedstawiono przyjęte w opracowaniu definicje najważniejszych pojęć. Pierwsze z nich - zasoby lokalne - nie jest rozumiane w sposób jednoznaczny zarówno w praktyce, jak i nauce, a poszczególni autorzy proponują jego różne definicje i typologie. S. Korenik (1999) uznaje za zasoby wszelkie elementy rzeczywistości mające znaczenie dla gospodarki danego obszaru, często o charakterze specyficznym, unikatowym, właściwym wyłącznie (lub prawie wyłącznie) danemu układowi lokalnemu. Interesującą refleksję na temat propozycji klasyfikacji i kumulatywnego wpływu zasobów lokalnych na rozwój proponuje M. Stanny (2013, s. 214), która uważa zasoby lokalne „za podstawowe czynniki rozwoju danego obszaru", a na potrzeby swojego badania uwzględnia ich trzy wymiary: miejsca (naturalne i korzyści miejsca), społeczne (zasoby pracy i wiedzy) i gospodarowania (zasoby materialne i finansowe). Inny zestaw typologii zasobów lokalnych prezentują S. Michalska i K. Zajda (2011), dzieląc je ze względu na częstość występowania, pocho-

\footnotetext{
2 Wyniki wielu badań wskazują (m.in. Dzikowska 2013; Sztando 2008, 2009), że SRG często charakteryzują się niską jakością, powierzchownością diagnozy i szablonowością proponowanych rozwiązań, a tym samym nie pełnią one funkcji skutecznego drogowskazu rozwoju. Wśród przyczyn tego stanu rzeczy można wymienić m.in. brak woli politycznej realizacji dokumentu, instrumentalne traktowanie opracowania jako sposobu na zwiększenie szans pozyskania środków zewnętrznych itp., a także niską jakość zawartości samej SRG, będącą często jednocześnie przyczyną, jak i efektem rangi, jaką dokument strategiczny posiada w danej gminie.
} 
dzenie, mobilność oraz na trajektorie ich wykorzystania. Warto podkreślić, że niezależnie od przytoczonej definicji w kontekście zasobów lokalnych mówi się o nich jako impulsach, źródłach czy czynnikach rozwoju, czyli jednoznacznie zgadzając się co do ich możliwej roli rozwojowej. W literaturze przedmiotu (Michalska i Zajda 2011) wskazuje się na pewną względną waloryzację zasobów - istotne jest dostrzeżenie ich możliwego znaczenia w wykorzystaniu gospodarczym. W niniejszym opracowaniu zasoby lokalne rozumiane są szeroko, jako każdy element rzeczywistości, który w danym momencie poszczególna gmina uznaje za zasób. Zaproponowane rozumienie zasobu lokalnego uwzględnia aktywną rolę władz gminnych i innych podmiotów biorących udział w tworzeniu SRG - wynika to z faktu, iż samo występowanie określonego zasobu (nawet bardzo cennego) samo z siebie nie stanowi o konkurencyjności obszaru (Jewtuchowicz 2005). Potrzebna jest decyzja i aktywność samorządu we współpracy z lokalną społecznością (lokalnymi liderów, przedsiębiorcami, stowarzyszeniami itp.), którzy zaangażują siły i środki w wykorzystanie danego zasobu. Pierwszym krokiem do takiego działania jest jednak świadomość, czyli identyfikacja zasobów, dla której znakomitą motywacją może być podjęcie przez gminę prac nad przygotowaniem dokumentu strategicznego ${ }^{3}$.

W opracowaniu stosuje się również pojęcie zasobu priorytetowego, za który uznaje się ten zasób (zasoby), który został uznany w SRG za relatywnie najważniejszy (najważniejsze), ogniskujący plany rozwojowe gminy. W niniejszym opracowaniu dla celów porządkujących (ze świadomością jej dyskusyjnego charakteru) wykorzystano ogólną typologię zasobów lokalnych zaproponowaną przez J. Falkowskiego (2016, s. 57), który wyróżnia następujące kategorie zasobów: przyrody, kultury, demograficzno-społeczne, ekonomiczne, technologiczne, planistyczne i organizacyjne. Proponowaną typologię uzupełniono: do kategorii „przyrody” zaliczono elementy infrastruktury turystycznej, do kategorii „ekonomiczne" zaliczono zasoby infrastrukturalne, dodano także kategorię zasobów „miejsca” w rozumieniu M. Stanny (2013) - tj. unikalnego położenia danej gminy w przestrzeni.

Pojęcie potencjału rozwojowego jest chętnie wykorzystywane w różnego typu badaniach z dziedziny geografii społeczno-gospodarczej czy ekonomii, a także bardzo często stanowi istotną kategorię w dokumentach strategicznych, ekspertyzach i programach rozwoju (np. Potencjały rozwojowe... 2014), brakuje jednak jasnych propozycji jego zdefiniowania. Według Słownika Języka Polskiego (sjp.pl) sam termin potencjał oznacza „czyjeś możliwości w danej dziedzinie”, co w kontekście rozwoju możemy w uproszczeniu rozumieć jako możliwość oddziaływania na procesy rozwojowe. W niniejszym opracowaniu pojęcie potencjału rozwojowego oznacza istniejący w danej gminie pewien wyjątkowy, unikatowy zasób (lub ich zespół) o charakterze materialnym bądź niematerialnym, którego wykorzystanie (zarówno wzmocnienie dotychczasowego wykorzystywania, jak i jego zainicjowanie) może wiązać się z relatywnie większymi (największymi) korzyściami dla gminy i jej mieszkańców oraz poprawą przewagi konkurencyjnej danego obszaru. Charakterystyczną cechą potencjału rozwojowego są więc jego specyficzność lub jakość, przeciwstawiane typowości i przeciętności zasobów występujących jeżeli nie powszechnie, to w większej liczbie gmin. W związku z powyższym oraz w obliczu ograniczonej ilości dostępnych środków finansowych tak istotna jest ocena, czy zasoby lokalne identyfikowane

3 Starsze opracowania dotyczące tworzenia strategii przywiązują dużą wagę do jej elementu diagnostycznego (np. Warda i Kłosowski 2001). Obecnie jednak coraz częściej wskazuje się, że sama diagnoza niekoniecznie musi być elementem samej strategii, ale osobnym, okresowo aktualizowanym dokumentem - swego rodzaju raportem o stanie gminy. 
oraz uznawane przez gminy za zasoby priorytetowe - mogą stanowić faktyczne potencjały rozwojowe.

Relację między zasobem lokalnym, priorytetowym zasobem lokalnym a potencjałem rozwojowym zaprezentowano na ryc. 1. Zgodnie z przedstawionymi definicjami najszerszy zakres posiada pojęcie zasobu lokalnego, natomiast pojęcia lokalnych zasobów priorytetowych oraz potencjałów rozwojowych są węższe, a ich zakres może (a nawet powinien) się pokrywać.

Optymalny wybór zasobów lokalnych w SRG ogniskujący dalsze działania gminy: lokalne zasoby priorytetowe toźsame z potencjalami rozwojowymi - efekt procesu identyfikacji, krytycznej analizy i selekcji

The optimal choice of local resources in local development strategy: local priority resources are consistent with local potentials of development - as an effect of identification, critical analysis and selection proces

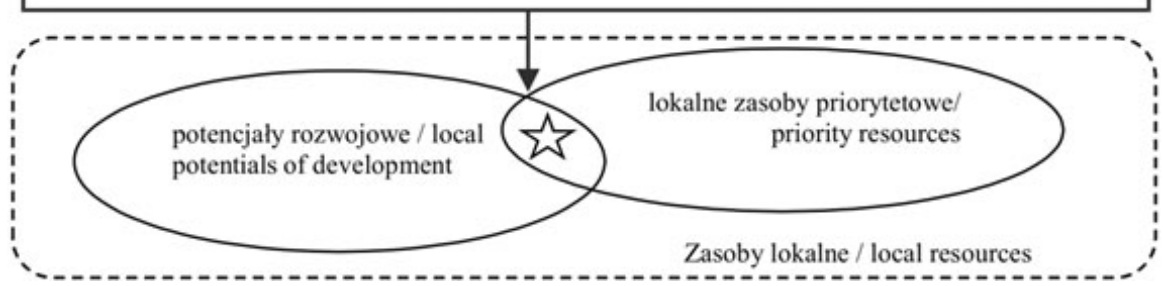

Ryc. 1. Relacja między potencjałami rozwojowymi, lokalnymi zasobami priorytetowymi a lokalnymi zasobami gminy

Relations between development potential, local priority resources and local commune resources

Źródło/Source: opracowanie własne/own elaboration.

\section{Zakres i metoda badania}

Niniejsze opracowanie zawiera udokumentowane badanie strategii rozwoju pięciu gmin wiejskich województwa śląskiego ${ }^{4}$, wybranych na podstawie kryterium poziomu rozwoju zrównoważonego (poziom rozwoju zrównoważonego oceniany zgodnie z wynikami badań dla 2014 r. w ramach projektu „Zrównoważony rozwój społeczno-gospodarczy jednostek samorządu terytorialnego" ${ }^{\prime 5}$ prowadzonego przez E. Sobczaka na Wydziale Administracji i Nauk Społecznych Politechniki Warszawskiej) oraz dostępności aktualnych dokumentów strategicznych. Są to: Pawłowice, Krupski Młyn, Suszec, Boronów oraz Chełm Śląski (gminy wiejskie województwa śląskiego posiadające aktualne dokumenty strategiczne i jednocześnie znajdujące się w pierwszej setce rankingu gmin pod względem zrównoważonego rozwoju na rok 2014).

Zastosowaną metodą badawczą jest analiza treści, a przedmiotem badania pięć SRG wybranych gmin. Należy w tym miejscu podkreślić, iż ze względu na charakter i cele bada-

${ }^{4}$ Ograniczona liczba gmin wynika z pilotażowego charakteru badania, których szerszy zakres prowadzony był w ramach rozprawy doktorskiej pt. „Obszary wiejskie województwa śląskiego - uwarunkowania, potencjały, perspektywy", przygotowywanej w Instytucie Geografii i Gospodarki Przestrzennej na Wydziale Geografii i Geologii Uniwersytetu Jagiellońskiego. Wybór gmin do badania powiązany z ich względnie wyższym poziomem rozwoju może być uzasadniony możliwym powiązaniem między osiągniętym poziomem a jakością rządzenia w danej gminie (w tym zarządzania strategicznego, którego przejawem jest strategia).

${ }^{5}$ Rankingi i szczegółowe informacje dostępne pod adresem: http://www.ans.pw.edu.pl/jst-index.php\#anchor-2 (dostęp 30 czerwca 2016 r.). 
nia (oraz różnorodność materiału badawczego) zastosowano jakościową odmianę analizy treści, znacząco odmienną od jej ujęcia ilościowego (szerzej np. Babbie 2000). W związku z powyższym w badaniu przyjęto podstawowe założenie, że dla uzyskania satysfakcjonujących wyników badania kluczowy jest sens wypowiedzi, a nie „policzalność” poszczególnych pojęć charakterystyczna dla ilościowej analizy treści. Zastosowanie jakościowej analizy treści wymagało utworzenia elastycznego klucza kategoryzacyjnego, który umożliwiał dostosowanie się do zróżnicowania struktury i zawartości oraz szczegółowości badanych SRG. Przyjęty w badaniu klucz kategoryzacyjny miał charakter dość ogólny (zbieżny z wyróżnionymi kategoriami zasobów lokalnych), pozwalający jednak na pewną wstępną kategoryzację zasobów wskazywanych jako istotne w poszczególnych gminach. Prócz samego zasobu istotne było także miejsce jego identyfikacji (część diagnostyczna strategii lub część projekcyjna, wdrożeniowa), a także powiązanie z działaniami/projektami planowanymi do realizacji przez gminę (informacje również zawarte w częściach projekcyjnych/ wdrożeniowych SRG). Warto podkreślić, że zaobserwowaną podczas badania trudnością jest problem rozróżnienia elementów rzeczywistości, które zostały uznane za zasób przez twórców dokumentu/władze gminy, od ogólnych warunków funkcjonowania danej gminy. Samo umieszczenie informacji o danym warunku rozwojowym jest wynikiem pewnego wyboru twórców strategii, jednak uznanie „ogólnych uwarunkowań" ${ }^{6}$ za zasoby lokalnie nie pozwoliłoby osiągnąć celu niniejszego opracowania. W związku z tym za zasoby lokalne uznano te elementy rzeczywistości, przy których podkreślono ich znaczenie lub umieszczono w części dokumentu jednoznacznie wskazującej na ich większą wagę. Przeprowadzone badanie można więc podzielić na trzy etapy:

a) Identyfikacja zasobów występujących w SRG zgodnie z treścią dokumentu (analiza części diagnostycznej, szczególnie „mocnych stron”7 - tabelarycznego podsumowania efektów analizy SWOT $^{8}$, tam gdzie taki element został zamieszczony w dokumencie);

b) określenie zasobów lokalnych priorytetowych (w danej gminie) zgodnie z treścią SRG (część diagnostyczna oraz część projekcyjna/wdrożeniowa, pojęcia/rozdziały typu „priorytety”, „wyróżniające potencjały”, itp.);

c) określenie związku między zidentyfikowanymi zasobami, a działaniami planowanymi do realizacji - ujętymi w części projekcyjnej/wdrożeniowej strategii (części dokumentu o charakterze wdrożeniowym, czyli np. „cele strategiczne”, „priorytety strategiczne”, „cele operacyjne”).

Każdemu z wymienionych etapów analizy można przypisać pewien wiodący fragment strategii, jednak należy mieć na uwadze zjawisko zróżnicowania struktury dokumentów strategicznych wynikające m.in. z braku jednolitego standardu tworzenia strategii, różnych podejść i oczekiwań władz gminy względem roli samego dokumentu.

${ }^{6}$ Do ogólnych uwarunkowań można zaliczyć m.in. aktualny poziom infrastruktury, liczbę szkół itp. - informacje o nich są najczęściej zamieszczanie w sposób opisowy w części diagnostycznej; stwierdza się ich zaistnienie, bez dodatkowego podkreślenia ich większej wagi rozwojowej.

7 Utożsamianie „mocnych stron” z zasobami uzasadnione jest właściwościami analizy SWOT - „mocne strony” to wewnętrzne cechy danej gminy o pozytywnym charakterze. Wydaje się, że kojarzenie zasobów i mocnych stron jest zbieżne z ich postrzeganiem przez twórców strategii, czego dowodzi komentarz w SRG Boronowa: „Stanowią one [mocne strony] zasoby, które można wykorzystać przy realizacji zakładanych planów” (s. 32).

8 Popularna technika porządkowania informacji powszechnie stosowana (choć w różnych wariantach) w dokumentach strategicznych. 
Tabela 1. Przedmiot badania - dokumenty strategiczne wybranych gmin wiejskich z obszaru województwa śląskiego

\begin{tabular}{|l|l|l|}
\hline & & \\
\hline & & \\
\hline & & \\
\hline
\end{tabular}

"na podstawie wyników badań A. Sobczaka w ramach projektu „Zrównoważony rozwój społeczno-gospodarczy jednostek samorządu terytorialnego", szczegółowe rankingi dostępne na stronie: http://www.ans.pw.edu.pl/ jst-index.php\#anchor-2d_(dostęp: 30 kwietnia 2017 r.)

Źródło: opracowanie własne.

Tabela 2. Elementy strategii rozwoju gmin wybrane do badania zasobów lokalnych z uzasadnieniem wyboru

\begin{tabular}{|c|c|c|c|}
\hline $\begin{array}{l}\text { Główne czę- } \\
\text { ści strategii } \\
\text { rozwoju }\end{array}$ & $\begin{array}{l}\text { Główne realizowane } \\
\text { funkcje }\end{array}$ & $\begin{array}{l}\text { Uszczegółowiony przedmiot } \\
\text { badania }\end{array}$ & $\begin{array}{c}\text { Uzasadnienie wyboru } \\
\text { (badanie zasobów } \\
\text { lokalnych) }\end{array}$ \\
\hline Diagnostyczna & $\begin{array}{l}\text { 1. Zebranie i syntetyzowanie } \\
\text { informacji o gminie i otocze- } \\
\text { niu z uwzględnieniem m.in: } \\
\text { - mieszkańców i ich potrzeb } \\
\text { - zasobów } \\
\text { - charakteru otoczenia } \\
\text { 2. Uzasadnienie kierunków } \\
\text { rozwojowych zaplanowanych } \\
\text { w dokumencie }\end{array}$ & $\begin{array}{l}\text { 1. Diagnoza o stanie gminy } \\
\text { 2. Wynik analizy SWOT } \\
\text { (mocne strony jako arty- } \\
\text { kulacja zasobów, pozostałe } \\
\text { - pomocniczo) }\end{array}$ & $\begin{array}{l}\text { Zaprezentowanie listy } \\
\text { zidentyfikowanych w gminie } \\
\text { zasobów lokalnych; także } \\
\text { z elementami hierarchizacji }\end{array}$ \\
\hline $\begin{array}{l}\text { Projekcyjna/ } \\
\text { wdrożeniowa }\end{array}$ & $\begin{array}{l}\text { Określenie najważniejszych } \\
\text { celów rozwojowych i zapla- } \\
\text { nowanie związanych z nim } \\
\text { zadań }\end{array}$ & $\begin{array}{l}\text { Fragmenty strategii: prio- } \\
\text { rytety, cele szczegółowe, } \\
\text { cele strategiczne, priorytety, } \\
\text { rozwoju, cele operacyjne itp. }\end{array}$ & $\begin{array}{l}\text { Narzędzie identyfikacji } \\
\text { priorytetów rozwojo- } \\
\text { wych - zadania związane } \\
\text { z poszczególnymi zasobami } \\
\text { lokalnymi świadczą o ich } \\
\text { większej wadze, koncentracji } \\
\text { wysiłków związanych z ich } \\
\text { wykorzystaniem }\end{array}$ \\
\hline
\end{tabular}

Źródło: M. Surmacz (2016) zmienione.

Warto podkreślić, że pozostając świadomym wielu ograniczeń dokumentów SRG, w niniejszym opracowaniu uznano ich dużą wartość jako unikatowego, względnie kompleksowego źródła danych o poszczególnych gminach, priorytetach rozwojowych itp. (szerzej o krytycznej ocenie strategii jako źródła danych: Surmacz 2016). 


\section{Zasoby lokalne identyfikowane przez gminy w SRG}

Informacje na temat zasobów lokalnych w SRG znajdują się przede wszystkim w części diagnostycznej dokumentów - forma ich przedstawienia (wylistowania) jednak różni się znacząco pomiędzy poszczególnymi strategiami, tj. może zostać przedstawiona w postaci tabeli lub wypunktowania jako efekt analizy SWOT, ale także i tekstu ciągłego opisującego poszczególne sfery funkcjonowania gminy.

Zasoby lokalne zidentyfikowane w wybranych SRG (tab. 3) cechują się bardzo dużym zróżnicowaniem (i poziomem ogólności/szczegółowości), co dowodzi ich szerokiego rozumienia przez autorów, a pośrednio także przez władze poszczególnych gmin. Takie rozumienie zasobów lokalnych, choć z jednej strony prowadzi do uzyskania kompleksowego obrazu warunków rozwoju gminy, z drugiej strony jednak niekoniecznie zwiększa poziom wiedzy adresata tekstu, a wręcz przeciwnie - prowadzić może do zwiększenia tzw. szumu informacyjnego (Sztando 2008), utrudniającego oparcie planów rozwojowych na wnioskach płynących z przeprowadzonej diagnozy. Zjawisko to utrudnia także samą analizę dokumentu, ponieważ w trakcie lektury strategii napotkano istotną trudność związaną z odróżnieniem tych elementów rzeczywistości, które gmina faktycznie uznaje za zasób lokalny od tego, co stanowi po prostu mniej istotną okoliczność jej funkcjonowania.

Jeśli chodzi o charakter zasobów identyfikowanych przez gminy, to dominują zasoby o charakterze przyrodniczym (także z uwzględnieniem infrastruktury turystyczno-rekreacyjnej) oraz ekonomicznym (z uwzględnieniem infrastruktury, poza turystyczną i rekreacyjną), a także społeczno-demograficznym. Nieco rzadziej gminy identyfikowały zasoby o charakterze planistycznym, organizacyjnym czy (najrzadziej) technologicznym. Prócz wymienionych kategorii zasobów wszystkie gminy wymieniały często korzystną lokalizację, która została przypisana do kategorii zasobów „miejsca”. W związku z tym zasobem warto podkreślić, że wynika on prawdopodobnie ze specyfiki gmin wiejskich wysoce zurbanizowanego i względnie dobrze skomunikowanego wewnętrznie województwa śląskiego. Wszystkie gminy, których SRG były przedmiotem badania, znajdują się w niewielkiej odległości (zarówno w ujęciu przestrzennym, jak i czasowym) od dużych aglomeracji istotnego, zewnętrznego czynnika rozwoju obszarów wiejskich województwa śląskiego.

Każda z badanych gmin przywiązywała znaczącą wagę do zasobów przyrodniczych, niejako automatycznie wiążąc je z możliwościami rozwoju funkcji turystycznej i rekreacyjnej. Za zasoby lokalne odpowiadające kategorii „przyrodnicze” uznawano przede wszystkim lasy, zbiorniki i cieki, formy ochrony przyrody, ale także krajobraz, tereny otwarte, zasoby wód podziemnych czy surowce naturalne (te ostatnie były właściwe dla gminy z rozbudowanym przemysłem wydobywczym). Jako cenny zasób lokalny gminy uznają również istniejące zagospodarowanie turystyczno-rekreacyjne, np. w postaci ścieżek rowerowych, obiektów sportowych.

We wszystkich badanych SRG gminy wymieniały zasoby, które mogą zostać przypisane do kategorii zasobów ekonomicznych. Przede wszystkim były to istniejące firmy i zakłady, ale także możliwe do zainwestowania tereny czy wyspecjalizowane rolnictwo. W ramach tej kategorii warto wspomnieć także o zasobach związanych z infrastrukturą - gminy za mocne strony uznawały wysoki poziom skanalizowania i wyposażenia w wodociągi, dobry stan dróg, funkcjonowanie oczyszczalni ścieków. Jedna z gmin jako swoją mocną stronę uznała również funkcjonowanie restauracji, co pokazuje wspomniane, bardzo szerokie rozumienie pojęcia zasobu lokalnego. 
Istotne znaczenie mają również zasoby o charakterze „demograficzno-społecznym”, związane zarówno z poziomem zaangażowania mieszkańców w działalność organizacji pozarządowych, jak i ich cechami (np. pracowitość), doświadczeniem czy istnieniem więzi sąsiedzkich.

Jeśli chodzi o zasoby kultury, to ich charakterystyczną cechą jest niematerialność („wiejski charakter”, „tradycja” itp.), choć dwie z pięciu gmin zaznaczyły, że na swoim obszarze posiadają także materialne zasoby kultury: kościoły, kapliczki czy pozostałości założeń dworskich.

Zasoby „technologiczne”, tuż obok zasobów „planistycznych”, identyfikowane były najrzadziej. Może to wynikać zarówno z braku ich wystąpienia na danym obszarze, jak i z nieświadomości gmin o możliwości uznania ich za zasób. Zidentyfikowanym w SRG zasobem „technologicznym” były nowoczesne technologie stosowane w lokalnym przemyśle oraz dostęp do internetu. Zasoby „organizacyjne” odnoszą się najczęściej do jakości i sprawności administracji samorządowej i dostępności do usług publicznych, a „planistyczne” do aktualności dokumentów planistycznych i strategicznych.

Na podstawie powyższych ustaleń można stwierdzić, że w badanych SRG (przynajmniej częściowo) odniesiono się do lokalnej specyfiki danego terytorium, co jest zjawiskiem pozytywnym (tab. 3). Brak takiego odniesienia jest uznawany bowiem za częstą, istotną słabość dokumentów SRG (np. Dzikowska 2013).

Tabela 3. Identyfikacja warunków rozwojowych uznawanych przez gminy za zasoby lokalne w dokumentach strategicznych.

\begin{tabular}{|c|c|c|}
\hline Kategoria & Zasoby lokalne - mocne strony SWOT & $\begin{array}{l}\text { Inne/uszczegółowione zasoby lokalne } \\
\text { wyróżnione w innych fragmentach SRG }\end{array}$ \\
\hline \multicolumn{3}{|c|}{ Pawłowice* } \\
\hline $\begin{array}{l}\text { przyrody } \\
\text { (+ turystyczne) }\end{array}$ & $x$ & $\begin{array}{l}\text { - tereny otwarte } \\
\text { - tereny zielone } \\
\text { - ścieżki rowerowe }\end{array}$ \\
\hline kultury & $x$ & $\begin{array}{l}\text { - wiejski charakter } \\
\text { - zasoby historyczne }\end{array}$ \\
\hline $\begin{array}{l}\text { demograficzno-spo- } \\
\text { łeczne }\end{array}$ & $x$ & - mieszkańcy \\
\hline $\begin{array}{l}\text { ekonomiczne } \\
\text { (+ infrastrukturalne) }\end{array}$ & $x$ & $\begin{array}{l}\text { - Kopalnia Węgla Kamiennego „Pniówek” } \\
\text { - rolnictwo } \\
\text { - produkt lokalny }\end{array}$ \\
\hline technologiczne & $x$ & $x$ \\
\hline planistyczne & $x$ & $x$ \\
\hline organizacyjne & $x$ & $x$ \\
\hline miejsca & $x$ & $\begin{array}{l}\text { - tereny pokopalnianie } \\
\text { - lokalizacja w pobliżu dużych miast }\end{array}$ \\
\hline \multicolumn{3}{|c|}{ Krupski Młyn } \\
\hline $\begin{array}{l}\text { przyrody } \\
\text { (+ turystyczne) }\end{array}$ & $\begin{array}{l}\text { - duża powierzchnia lasów } \\
\text { - zasoby wód podziemnych (główne } \\
\text { zbiorniki wód podziemnych w Polsce } \\
\text { - Dolina Małej Panwi }\end{array}$ & $\begin{array}{l}\text { - obszar Chronionego Krajobrazu Lasów } \\
\text { Lublinieckich należących do Europej- } \\
\text { skiej Sieci Ekologicznej ECONET PL } \\
\text { - obszar dorzecza Małej Panwi objęty } \\
\text { programem Natura } 2000 \\
\text { - czystość środowiska }\end{array}$ \\
\hline
\end{tabular}




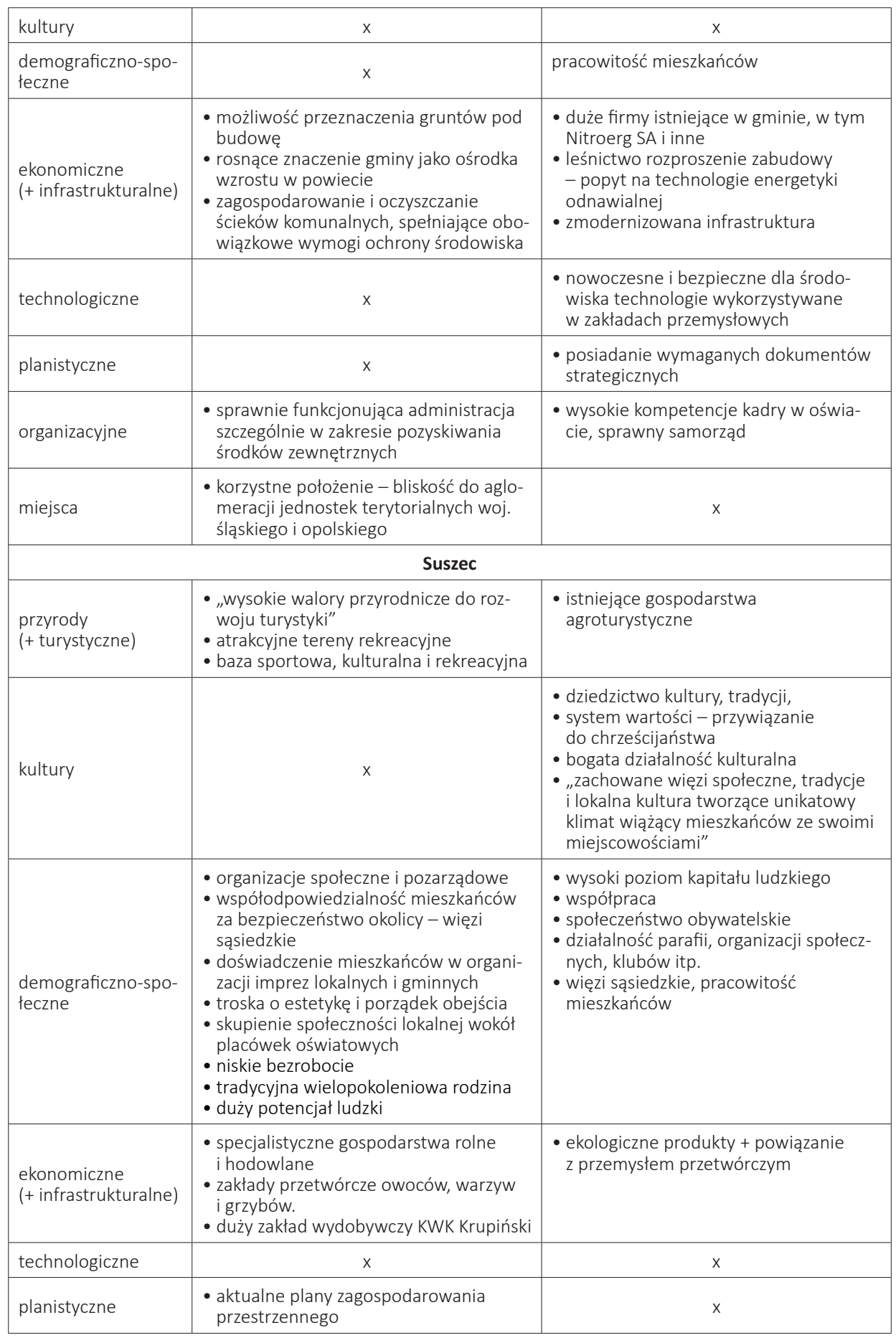




\begin{tabular}{|c|c|c|}
\hline organizacyjne & • kompetentni urzędnicy & $\begin{array}{l}\text { - wysokie kompetencje kadry w oświacie } \\
\text { - sprawny samorząd }\end{array}$ \\
\hline miejsca & - dobre położenie geograficzne & $x$ \\
\hline \multicolumn{3}{|c|}{ Boronów } \\
\hline $\begin{array}{l}\text { przyrody } \\
\text { (+ turystyczne) }\end{array}$ & $\begin{array}{l}\text { - Park Krajobrazowy Lasy nad Górną } \\
\text { Liswartą) } \\
\text { - obiekty sportowe (także siłownia } \\
\text { zewnętrzna) } \\
\text { - ścieżki pieszo-rowerowe }\end{array}$ & $x$ \\
\hline kultury & - zabytkowy kościół, kapliczki & $x$ \\
\hline $\begin{array}{l}\text { demograficzno-spo- } \\
\text { łeczne }\end{array}$ & $\begin{array}{l}\text { - wysoki poziom integracji społecznej } \\
\text { mieszkańców } \\
\text { - aktywnie działające na terenie gminy } \\
\text { stowarzyszenia } \\
\text { - Ochotnicza Straż Pożarna wpisana } \\
\text { do KSRG }\end{array}$ & $x$ \\
\hline $\begin{array}{l}\text { ekonomiczne } \\
\text { (+ infrastrukturalne) }\end{array}$ & $\begin{array}{l}\text { - obecność bazy paliw } \\
\text { - restauracja } \\
\text { - wysoki poziom skanalizowania gminy, } \\
\text { - linodociągi } \\
\text { - dobry stajowa i dośćc duża ilość połączeń } \\
\text { - gęsta sieć dróg wojewódzḱ }\end{array}$ & $x$ \\
\hline technologiczne & - dostęp do internetu & $x$ \\
\hline planistyczne & $x$ & $x$ \\
\hline organizacyjne & $\begin{array}{l}\text { - dostęp do usług publicznych: ośrodek } \\
\text { zdrowia, ośrodek kultury, przedszkola, } \\
\text { szkoły }\end{array}$ & $x$ \\
\hline miejsca & - dostępność przestrzenna & $x$ \\
\hline \multicolumn{3}{|c|}{ Chełm Śląski } \\
\hline $\begin{array}{l}\text { przyrody } \\
\text { (+ turystyczne) }\end{array}$ & $\begin{array}{l}\text { - zbiornik Dziećkowice } \\
\text { - tereny rekreacyjne } \\
\text { - walory ekologiczne i środowiskowe } \\
\text { - złoża węgla i glinki }\end{array}$ & $\begin{array}{l}\text { - stare drzewa jako przyszłe pomniki } \\
\text { przyrody } \\
\text { - warunki glebowo-przyrodnicze sprzyja- } \\
\text { jące produkcji rolnej }\end{array}$ \\
\hline kultury & $x$ & - pozostałości założeń parku dworskiego \\
\hline $\begin{array}{l}\text { demograficzno-spo- } \\
\text { łeczne }\end{array}$ & $x$ & $x$ \\
\hline $\begin{array}{l}\text { ekonomiczne } \\
\text { (+ infrastrukturalne) }\end{array}$ & $\begin{array}{l}\text { - dobrze położone tereny budowlane } \\
\text { - linia kolejowa }\end{array}$ & $x$ \\
\hline technologiczne & $x$ & $x$ \\
\hline planistyczne & $x$ & $x$ \\
\hline organizacyjne & $\begin{array}{l}\text { - dobra kondycja finansowa gminy } \\
\text { - dobra infrastruktura } \\
\text { społeczno-edukacyjna }\end{array}$ & $x$ \\
\hline miejsca & $\begin{array}{l}\text { - bliskość ważnych szlaków } \\
\text { komunikacyjnych } \\
\text { - dostępność przestrzenna }\end{array}$ & $x$ \\
\hline
\end{tabular}

$x$ - nie stwierdzono, *brak analizy SWOT w strategii.

Źródło: SRG Krupski Młyn, Analiza SWOT (s. 21); SRG Suszec, Czynniki analizy SWOT

(s. 25-26); SRG Boronów, Podsumowanie - analiza SWOT (s. 33); SRG Chełm Ślqaski, Czynniki analizy SWOT/ TOWS (s. 59). 


\section{Priorytetowe zasoby lokalne a lokalne potencjały rozwoju gmin}

Identyfikowane przez gminy zasoby priorytetowe, tj. takie, które gmina uważa za ważne i jednocześnie planuje w związku z nimi podjęcie określonych działań w badanych SRG, ograniczają się właściwie do trzech kategorii: zasobów przyrody, demograficzno-społecznych i ekonomicznych (tab. 4). Warto zaznaczyć, że w badanych strategiach niekoniecznie istnieje spójność między mocnymi stronami (tab. 3) a zasobami priorytetowymi, które zdawałoby się - powinny stanowić pewne uszczegółowienie mocnych stron.

Wszystkie badane gminy za zasób priorytetowy uznają zasoby przyrodnicze, planując jednocześnie powiązane z nimi różnego rodzaju działania związane z realizacją funkcji turystycznej i rekreacyjnej. W tym kontekście warto podkreślić - co widać wśród pięciu badanych SRG (ale także np. Sołtys 2016) - że wiele gmin pokłada duże nadzieje w rozwoju turystyki i rekreacji w oparciu o swoje zasoby lokalne, czyli krajobraz, uwarunkowania przyrodnicze, ukształtowanie terenu, dostęp do cieków i zbiorników wodnych, lasów itp. Jednocześnie jednak w literaturze przedmiotu mówi się (m.in. Durydiwka 2012) o przecenianiu znaczenia tej szansy na rozwój - turystyka nie stanowi remedium na problemy rozwojowe, choć jednocześnie może stanowić jeden z elementów wielofunkcyjnego rozwoju obszarów wiejskich, szczególnie na tych obszarach, gdzie występują unikalne warunki przyrody lub istnieje wyjątkowy pomysł na aktywizację zasobów przeciętnych ${ }^{9}$. Przykładem pewnej pomysłowości gmin w zakresie wykorzystania swoich zasobów przyrodniczych są plany Krupskiego Młyna i Suszca w kierunku rozwoju wyspecjalizowanej turystyki i specyficznych form rekreacji (np. kajakarstwo, szlaki narciarstwa biegowego czy łowiectwo).

Drugą grupą zasobów priorytetowych są zasoby o charakterze demograficzno-społecznym, które w badanych SRG można sprowadzić do mieszkańców gmin (w ogólności) i ich poszczególnych cech. Choć jest to zasób w pewien sposób uniwersalny, to „jakość" mieszkańców może odegrać istotną rolę w rozwoju gminy. W każdej z badanych SRG zaplanowano działania adresowane do mieszkańców związane z ich kształceniem (np. w dziedzinie przedsiębiorczości), aktywizacją czy też promocją zdrowia.

Do zasobów uznawanych za priorytetowe należą również te o charakterze ekonomicznym: istniejące w gminie zakłady przemysłowe i firmy, prowadzona działalność rolnicza, tereny nadające się pod inwestycje lub rozwój funkcji mieszkaniowej. W kontekście zasobów gospodarczych warto podkreślić, że choć gminy doceniają istnienie na swoim obszarze dużego pracodawcy (niewątpliwie cennego zasobu), to jednak są świadome konieczności zróżnicowanych funkcji uzupełniających (także na wypadek ewentualnych zagrożeń związanych z ewentualnym zakończeniem jego działalności). Związane z zasobami gospodarczymi działania podejmowane przez gminę zwykle odnoszą się do planów udzielenia wsparcia edukacyjnego, rozbudowy infrastruktury, udostępnienia terenów, pobudzenia przedsiębiorczości lokalnej, promocji lokalnego produktu.

Warto podkreślić, że - choć obserwacja ta jest sformułowana na podstawie mocno ograniczonych badań - gminy w SRG częściej planują działania odpowiadające bieżącemu zapotrzebowaniu mieszkańców niż takie, które mogłyby stanowić impuls rozwojowy oparty o zasoby lokalne (działania powiązane z identyfikowanymi zasobami priorytetowymi są raczej standardowe, nie mają charakteru innowacyjnego). Dobrym przykładem

\footnotetext{
9 Rolę pomysłu w kształtowaniu rozwoju lokalnego doceniają teoretycy i praktycy odnowy wsi (Błąd 2007). Przykładem może być np. względny sukces wsi, które zdecydowały się na utworzenie wiosek tematycznych.
} 
ilustrującym to zjawisko jest SRG gminy Suszec (s. 29), gdzie sformułowano działania priorytetowe odnoszące się do określonych celów strategicznych. W tym wypadku np. inwestowanie w specjalizację rolnictwa (projekt „Kompleksowy program szkolenia rolników, podnoszenia ich świadomości rolnej, integrowania gospodarstw rolnych i pomoc w tworzeniu grup producenckich") lub działania związane z zainteresowaniem inwestorów dostępnymi terenami (projekt „Stworzenie internetowej bazy danych o wolnych terenach inwestycyjnych”) są określane jako „działania o mniejszej istotności, rekomendowane do realizacji w dłuższym okresie" i ustępują miejsca takim projektom jak: skanalizowanie gminy, budowa chodników w gminie czy zagospodarowanie terenów wokół remizo-świetlicy i domu kultury itp. (określanym jako działania priorytetowe, rekomendowane do szybkiego wdrożenia).

Tabela 4. Zasoby uznane $w$ badanych dokumentach strategii rozwoju gminy za priorytetowe wraz z powiązanymi działaniami

\begin{tabular}{|c|c|c|}
\hline 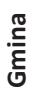 & Kategoria zasobu priorytetowego & $\begin{array}{l}\text { Uzasadnienie uznania za zasób priorytetowy } \\
\text { (zaplanowane w strategii działania związane } \\
\text { z zasobem) }\end{array}$ \\
\hline 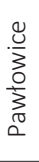 & $\begin{array}{l}\text { 1. przyrody (tereny otwarte, zielone) } \\
\text { 2. demograficzno-społeczne (mieszkańcy) } \\
\text { 3. gospodarcze }\end{array}$ & $\begin{array}{l}\text { 1. rozwój obszarów rekreacyjnych oraz ochrona } \\
\text { terenów otwartych przed zabudową } \\
\text { 2. wsparcie rozwoju kwalifikacji oraz program } \\
\text { zdrowotny } \\
\text { 3. promowanie produktu lokalnego }\end{array}$ \\
\hline 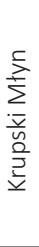 & $\begin{array}{l}\text { 1. demograficzno-społeczne (mieszkańcy) } \\
\text { 2. przyrodnicze (dostępność rzeki i lasy) } \\
\text { 3. gospodarcze (rozproszona zabudowa-możli- } \\
\text { wość rozwoju energetyki odnawialnej; dostępność } \\
\text { i atrakcyjność terenów inwestycyjnych, istniejące } \\
\text { firmy) }\end{array}$ & $\begin{array}{l}\text { 1. aktywizacja przedsiębiorczości, wspar- } \\
\text { cie zdolnych uczniów, wsparcie starszych } \\
\text { i niepełnosprawnych } \\
\text { 2. rozwój turystyki i rekreacji specjalistycznej: kaja- } \\
\text { karstwa, łowiectwa, narciarstwa biegowego } \\
\text { 3. rozwój energetyki odnawialnej; uzbrojenie } \\
\text { terenów inwestycyjnych; wsparcie innowacyjności } \\
\text { istniejących firm }\end{array}$ \\
\hline $\begin{array}{l}\stackrel{u}{N} \\
N \\
心 \\
\sim\end{array}$ & $\begin{array}{l}\text { 1. demograficzno-społeczne } \\
\text { 2. przyrody } \\
\text { 3. gospodarcze (rolnictwo specjalistyczne) }\end{array}$ & $\begin{array}{l}\text { 1. działania na rzecz mieszkańców: program } \\
\text { zdrowotny } \\
\text { 2. program rozwoju turystyki z naciskiem } \\
\text { na agroturystykę } \\
\text { 3. udzielenie wsparcia rolnikom }\end{array}$ \\
\hline 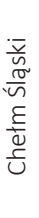 & $\begin{array}{l}\text { 1. przyrody (m.in. zbiornik wodny) } \\
\text { 2. gospodarcze (warunki rozwoju mieszkalnictwa) } \\
\text { 3. demograficzno - społeczne (mieszkańcy) }\end{array}$ & $\begin{array}{l}\text { 1. „uczynienie z Chełmu Śląskiego, znaczącego dla } \\
\text { gospodarki Gminy, ośrodka rekreacji weekendowej } \\
\text { mieszkańców aglomeracji śląskiej” (Strategia... } \\
\text { s. 32) - rozbudowa infrastruktury } \\
\text { 2. plany uzbrojenia terenu pod zabudowę } \\
\text { mieszkaniową } \\
\text { 3. szkolenia z przedsiębiorczości dla mieszkańców }\end{array}$ \\
\hline 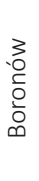 & $\begin{array}{l}\text { 1. przyrody (m.in. z Park Krajobrazowy Lasy nad } \\
\text { Górną Liswartą) } \\
\text { 2. demograficzno-społeczne (mieszkańcy i organi- } \\
\text { zacje pozarządowe) }\end{array}$ & $\begin{array}{l}\text { 1. jasna hierarchizacja w postaci rangowania oraz } \\
\text { zaplanowanie działań związanych z rozbudową } \\
\text { infrastruktury wokół } \\
\text { 2. zaplanowanie szkoleń z zakresu aktywizacji mło- } \\
\text { dzieży oraz organizacji wsparcia dla działających } \\
\text { w gminie organizacji pozarządowych }\end{array}$ \\
\hline
\end{tabular}

Źródło: opracowanie własne. 


\section{Podsumowanie i wnioski}

Przeprowadzone badanie pięciu SRG gmin wiejskich województwa śląskiego pozwoliło na uzyskanie kilku istotnych wniosków, które - z jednej strony - odpowiadają na postawione na wstępie pytania badawcze, z drugiej prezentują potrzebę szerszych i pogłębionych badań także, co szczególnie ważne, o charakterze aplikacyjnym.

Odpowiadając na pierwsze pytanie badawcze dotyczące tego, jakie zasoby lokalne są identyfikowane w SRG badanych gmin wiejskich, należy stwierdzić, że ich szczegółowość i tematyka jest silnie zróżnicowana pomiędzy poszczególnymi SRG. Różnice te - co oczywiste - wynikają po części z naturalnych zróżnicowań związanych z lokalną specyfiką gmin, jednak wydaje się, że ich przyczyną jest również problem rzetelności przeprowadzonej diagnozy i rzeczywistej chęci oparcia prospektywnych części strategii o jej wyniki. Choć wygląda na to, że zasoby lokalne odgrywają znaczą rolę w teoretycznym myśleniu o rozwoju, w praktyce ich identyfikacja może powodować problemy polegające najczęściej na braku czytelnego rozróżnienia tego, co gmina faktycznie uznaje za cenny zasób od tego, co stanowi ogólne uwarunkowanie rozwojowe gminy. Czasami także opis danego zasobu (bardzo ogólne jego ujęcie lub z drugiej strony bardzo szczegółowa charakterystyka) nie pozwala na powiązanie z nim konkretnych działań rozwojowych. Tym samym, choć wydaje się, że istnieje ogólna zgoda dotycząca potrzeby rzetelnego rozeznania zasobów, którymi dysponuje dana gmina i zaplanowania ich możliwego wykorzystania, nie do końca widoczna jest w SRG krytyczna refleksja nad wartością danego zasobu lokalnego z perspektywy rozwoju danej gminy (nie do końca również widoczne jest oparcie przyszłego rozwoju o zidentyfikowane zasoby priorytetowe, o czym poniżej). Choć częściowo gminy podejmują próbę waloryzacji swoich zasobów i określenia mocnych stron w przeprowadzonej analizie SWOT, to we wszystkich pięciu badanych strategiach zauważalną praktyką było szczegółowe przedstawienie rzeczywistości funkcjonowania danej gminy (zajmujący znaczną objętość dokumentu jako takiego), pozostające niejako „obok” identyfikowanych później w strategiach SWOT mocnych stron. Warto podkreślić, że zdarzały się przykłady identyfikowania takich zasobów lokalnych, które są wynikiem pewnego niesztampowego sposobu myślenia o rozwoju - uświadomienia sobie wieloaspektowości określonego zjawiska i uznania go za zasób w pewnym określonym ujęciu (co należy docenić, ponieważ niedostrzeganie wieloaspektowości zjawisk jest uznawane za jedną z barier skutecznego zarządzania rozwojem - Sztando 2008). Dobrym przykładem może być uznanie w SRG Suszec za swoisty zasób lokalny zjawiska rozproszenia zabudowy (zjawisko samo w sobie jest uznawane raczej za barierę rozwojową), które sprzyja - zdaniem twórców strategii rozwojowi energetyki odnawialnej w gminie.

Jeśli chodzi o drugie pytanie badawcze dotyczące możliwości identyfikacji w SRG zasobów uznanych za priorytetowe, to badane dokumenty częściowo zdają się potwierdzać tezę o występowaniu zjawiska unikania przez gminy dokonywania (a przynajmniej ich artykulacji w strategii) strategicznych wyborów (Sztando 2008) - tj. wyborów tych zasobów, których wykorzystanie w obliczu ograniczonego dostępu do funduszy może przynieść najkorzystniejsze skutki dla gminy. Z drugiej strony jednak możliwe jest znalezienie w SRG stwierdzeń pozwalających na identyfikację (częściowo w sposób pośredni) tych z zasobów, które gmina uważa za priorytetowe (czyli najbardziej obiecujące) i w związku z nimi planuje podjęcie określonych działań. 
Odpowiedź na trzecie pytanie - czy zasoby uznane za priorytetowe stanowią faktyczne potencjały rozwojowe - jest niejednoznaczna. Na podstawie przeprowadzonego badania można bowiem stwierdzić, że większość zasobów uznawanych przez gminy za priorytetowe ma charakter typowy, uniwersalny, powiązany jednocześnie z oczywistymi, standardowymi działaniami aktywizującymi/wykorzystującymi dany zasób. Z drugiej strony jednak, część ze zidentyfikowanych zasobów priorytetowych i zaplanowanych w związku z nimi działań świadczy o tym, że w gminach istnieje pewna umiejętność krytycznego odniesienia się do pozostających w ich dyspozycji możliwości rozwoju oraz pewne otwarte na innowację podejście, które pozwala dostrzec niesztampowe rozwiązania. Część ze zidentyfikowanych w badaniu zasobów priorytetowych można więc uznać za faktyczne potencjały rozwojowe (zgodnie z przyjętą definicją), ponieważ spełniają one kryterium unikalności i jakości, a jednocześnie, jak się wydaje, można budować w oparciu o nie długoterminowy rozwój gminy (przykładem jest np. wyspecjalizowane rolnictwo ekologiczne powiązane z lokalnym przemysłem jako zasób priorytetowy zidentyfikowany w SRG Suszec).

Udzielenie odpowiedzi na postawione pytania badawcze pozwalają na refleksję związaną z głównym celem pracy dotyczącym oceny jakości identyfikowanych przez gminy zasobów lokalnych w kontekście ich możliwego znaczenia jako potencjałów rozwojowych. Choć na podstawie pilotażowej analizy pięciu SRG trudno o formułowanie szerszych prawidłowości, wydaje się, że można zaryzykować wniosek dotyczący raczej niskiej jakości elementów rzeczywistości uznawanych przez gminy za zasób (w tym zasoby priorytetowe) w kontekście ich wykorzystania jako potencjału rozwojowego. Uzasadnieniem dokonanej oceny jest z jednej strony typowość i uniwersalność większości identyfikowanych zasobów rozwojowych (z pewnymi jednak wyjątkami), z drugiej jednak - i to być może ważniejsze - proponowane, standardowe sposoby ich wykorzystania. Wniosek powyższy warto powiązać z rolą samorządu w procesie rozwoju. Uznaje się, że polskie samorządy przede wszystkim mają na celu realizację ustawowo sprecyzowanych zadań, w tym także dotyczących zaspokajania potrzeb lokalnej społeczności. W takim ujęciu identyfikowane w SRG zasoby priorytetowe oraz planowane w związku z nimi działania można byłoby pewnie ocenić jako wystarczające. Obecnie jednak coraz częściej wskazuje się, że samorząd powinien być motorem rozwoju lokalnego i w swoim działaniu wychodzić poza zaspokajanie bieżących potrzeb lokalnej społeczności (Sztando 2008), a jedną z promowanych koncepcji rozwoju jest oparcie go o zasoby lokalne (choć przy jednoczesnym wykorzystaniu szans zewnętrznych). W związku z powyższym oraz ze względu na stałą ograniczoność środków finansowych (co jest szczególnie ważne w perspektywie możliwych zmian w dystrybucji środków unijnych po 2020 r.) nieoptymalny wybór zasobów priorytetowych, skutkujący rozpraszaniem środków i utratą możliwości wykorzystania faktycznych możliwości niesionych przez dostępne zasoby, może stanowić znaczące utrudnienie rozwoju gmin. Obserwacja ta pozwala na sformułowanie postulatu weryfikacji ustaleń strategii rozwojowych dotyczących zasobów lokalnych i możliwości (oraz szczegółowych propozycji) ich wykorzystania dla zdynamizowania rozwoju lokalnego. Działanie to w wymaga jednak szerszych badań, wsparcia eksperckiego, a nieraz także odwagi podjęcia wyrazistych decyzji - kluczowego elementu skutecznego zarządzania strategicznego. 


\section{Literatura}

Babbie E. 2004, Badania społeczne w praktyce, Wydawnictwo Naukowe PWN, Warszawa.

Błąd M., 2007, Kilka refleksji na temat odnowy wsi, [w:] M. Kłodziński, M. Błąd, R. Wilczyński (red.), Odnowa wsi w integrujqcej się Europie, Instytut Rozwoju Wsi i Rolnictwa PAN, Warszawa, s. 105-112.

Brol R., 1998, Rozwój lokalny - nowa logika rozwoju gospodarczego, Gospodarka lokalna w teorii i praktyce, Prace Naukowe AE we Wrocławiu, 785, Wrocław.

Durydiwka M., 2012, Czynniki rozwoju i zróżnicowanie funkcji turystycznej na obszarach wiejskich w Polsce, Wydział Geografii i Studiów Regionalnych UW, Warszawa.

Dzikowska E., 2013, Plany Rozwoju Lokalnego - oczekiwania a rzeczywistość, Wieś i Rolnictwo, 4 (161), s. 133-148.

Falkowski J., 2016, Klasyfikacja zasobów, walorów i czynników rozwoju lokalnego na przykładzie wybranych gmin województwa kujawsko-pomorskiego, Studia Obszarów Wiejskich, 44, s. 55-74.

Internetowy Słownik Języka Polskiego, www.sjp.pl

Jewtuchowicz A., 2013, Terytorium i współczesne dylematy jego rozwoju, Wydawnictwo Uniwersytetu Łódzkiego, Łódź.

Kłodziński M., 2009, Znaczenie i potrzeba tworzenia strategii rozwoju gminy, Zagadnienia Ekonomiki Rolnej, 319 (2), s. 33-47.

Korenik S., 1999, Rozwój regionu ekonomicznego na przykładzie Dolnego Śląska, Wydawnictwo Akademii Ekonomicznej, Wrocław.

Michalska S., Zajda K., 2011, Trajektorie wykorzystania zasobów lokalnych w procesie rozwoju partnerstw terytorialnych. Case study lokalnych grup działania "Dolina Karpia" oraz "Kraina Rawki", Wieś i Rolnictwo, 4, 153, s. 123-138.

Parysek J., 2001, Podstawy gospodarki lokalnej, Wydawnictwo UAM, Poznań.

Parysek J., 2015, Rola lokalnego samorzqdu terytorialnego w rozwoju społeczno-gospodarczym i przestrzennym gmin, Ruch prawniczy, ekonomiczny i socjologiczny, LXXVII, 3, s. 27-46.

Potencjały rozwojowe i zarzqdzanie strategiczne w gminach Mazowsza. Raport z wyników badania IDI w samorzqdach gminnych województwa mazowieckiego, 2014, Trendy rozwojowe Mazowsza, 14, Mazowieckie Biuro Planowania Regionalnego, Warszawa.

Ray Ch., 2001, Culture Economies: a perspective on local rural development in Europe, Centre for Rural Economy, University of Newcastle upon Tyne, Newcastle.

Rzeszutko-Piotrowska M., 2013, Strategiczne planowanie rozwoju gospodarczego w polskich gminach, [w:] Nierówności społeczne a wzrost gospodarczy. Kryzys finansów publicznych - przyczyny, implikacje, perspektywy spójności społeczno-ekonomicznej, Wydawnictwo Uniwersytetu Rzeszowskiego, zeszyt 34, Rzeszów s. 159-178.

Sekuła A., 2005, Bariery Rozwoju Lokalnego, [w:] B. Filipiak, A. Szewczuk, Z. Zychowicz (red.), Samorząd terytorialny w zintegrowanej Europie, Zeszyty naukowe, 401, Uniwersytet Szczeciński, Szczecin, s. 587-600.

Stanny M., 2013, Przestrzenne zróżnicowanie rozwoju obszarów wiejskich w Polsce, IRWiR PAN, Warszawa.

Surmacz M., 2016, Strategie rozwoju gmin jako źródło danych w badaniach geograficznych [w:] A. Zborowski (red.), Człowiek, Społeczeństwo, Przestrzeń, t. 10, Myczkowce-Kraków, s. 169-181.

Sztando A., 2008, Typowe problemy planowania strategicznego w polskich samorzadach [w:] M. Dylewski (red.), Ekonomiczne i organizacyjne instrumenty wspierania rozwoju lokalnego i regionalnego. Rozwój, innowacyjność, infrastruktura, Zeszyty Naukowe, 501, Ekonomiczne Problemy Usług, 22, Uniwersytet Szczeciński, Szczecin, s. 193-202. 
Sztando A., 2009, Przedmiot i podmiot strategii rozwoju gminy [w:] M. Dylewski (red.), V Forum samorzqdowe. Samorzad terytorialny w zintegrowanej Europie, Zeszyty Naukowe, 526, Ekonomiczne Problemy Usług, 29, Uniwersytet Szczeciński, Szczecin, s. 467-473.

Warda J., Kłosowski W., 2001, Wyspy szans. Jak budować strategie rozwoju lokalnego? Wydawnictwo W\&K, Bielsko-Biała.

Wiatrak A.P., 2011, Strategie rozwoju gmin wiejskich. Podstawy teoretyczne, ocena przydatności i znaczenie w przemianach strukturalnych obszarów Wiejskich, IRWiR PAN, Warszawa.

\section{Dokumenty strategiczne}

Strategia Rozwoju Gminy Pawłowice od 2015 do 2025 roku „Pawłowice 2025”, 2015, Załącznik do Uchwały Rady Gminy Pawłowice, Urząd Gminy Pawłowice.

Strategia Rozwoju Gminy Krupski Młyn na lata 2016-2026, 2015, Załącznik do Uchwały Nr XV/105/16 Rady Gminy Krupski Młyn z dnia 29 lutego 2016, Urząd Gminy Krupski Młyn.

Strategia Rozwoju Gminy Suszec do roku 2022, 2007, Załącznik do Uchwały NrXI/58/77/2007 Rady Gminy Suszecz dnia 30 sierpnia 2007r., Urząd Gminy Suszec.

Strategia Rozwoju Gminy Chełm Ślq̨ski na lata 2004-2020 Chełm Śląski: dobre miejsce do zamieszkania, 2004, Uchwała Nr XX/112/2004 Rady Gminy Chełm Śląski z dnia 23 lipca 2004 r., Urząd Gminy Chełm Śląski.

Strategia Rozwoju Gminy Boronów na lata 2016-2025, 2016, Stowarzyszenie Animacji i Rozwoju Lokalnego, Boronów.

\section{Inne źródła}

Dane opracowane i udostępnione w ramach projektu „Zrównoważony rozwój społeczno-gospodarczy jednostek samorządu terytorialnego" prowadzonego przez E. Sobczaka na Wydziale Administracji i Nauk Społecznych Politechniki Warszawskiej http://www.ans. pw.edu.pl/jst-index.php\#anchor-2d (dostęp: 30 kwietnia 2017 r.)

\section{Summary}

The main goal of this article is to evaluate the quality of local development potential (the unique and relative more promising resources) identified in the development strategies of rural communes in Silesian Province, Poland. The study encompassed 5 documents from rural communes chosen in view of their development level (as a pilot study to a more complex research). The research focused on these parts of the documents concerning the SWOT matrix (especially the strengths category, which in this case is identified as local resources), as well as the main goals and priorities of strategies. The study of commune development strategies has shown that:

1) Many local resources (natural, cultural, economic, etc.) are specified, but they are usually typical and may be mistaken with local conditions. They may also generate 'information noise', rendering it difficult for users of strategic documents to choose the most promising local resources.

2) The main purpose of a local strategy document is to make the key choices of available options. Communes specify the priority resources and plan related activities 
as main operational goals. Their identification and description is not detailed and inspiring enough to boost the local development process. There is also a problem associated with the awareness of many aspects of each resource.

3) It seems that only a few of identified priority resources can be rightfully named as local development potential. It can be a significant problem because of limited financial resources - rural communes do not take full advantage of opportunities because of lack of knowledge as well as dissipation of funds for many activities which may be important in the short term but do not have positive impact on local economy in the long term.

To sum up, it seems that even though there is a common consensus that local resources are an important source of development, it is very difficult to decide responsibly which resources are the most promising and which resources need further actions such as e.g. better funding. In practice it seems that the quality of the most important local resources as local development potential in rural commune strategies should be verified. 
http://rcin.org.pl 